\title{
Urban ecosystems as locations of distribution of alien aquatic plants
}

\author{
Mariana Prokopuk*, Lesya Zub \\ Institute for Evolutionary Ecology, National Academy of Sciences of Ukraine, \\ 03143, Kyiv, 37 Lebedeva str., Ukraine
}

\begin{abstract}
Prokopuk, M., Zub, L., 2020. Urban ecosystems as locations of distribution of alien aquatic plants. Folia Oecologica, 47 (2): 159-167.

Peculiarities of alien macrophytes invasions into aquatic ecosystems located at urban landscapes were investigated on an example of water bodies, rivers and streams located within the Kyiv City (Ukraine). There have been recognised seven species of alien aquatic macrophytes established at the territory of Kyiv City, representing $11 \%$ of the hydrophilic flora of the city. The representatives of the recent invasions Egeria densa, Elodea nuttallii and Pistia stratiotes in comparison with Elodea canadensis were characterized by a wider ecological valence concerning the contents of nitrogen compounds in water. Significant variability of morphometric parameters of coenopopulations of alien species formed in different environmental conditions was recognised. There was observed that the individuals of Pistia stratiotes from eutrophic water bodies formed significantly larger surface organs, and the individuals from meso-eutrophic reservoir had a larger number of leaves in the rosette, and more numerous and longer roots. The alien macrophytes species dwelling in the water bodies of the city were characterized by wide ecological amplitudes, high stress tolerance, high reproduction rate, high naturalization degree, allowing these species to use the resources of their new environment inaccessible for the local species and significantly affecting the ecosystem homeostasis and transformation.
\end{abstract}

Keywords

invasive aquatic plants, macrophytes, Ukraine

\section{Introduction}

Increasing rate of landscapes urbanization has been recognized as one of the most important factors exerting negative impacts on biodiversity (KEATING, 1993). At such territories, thorough transformation of natural complexes takes place. In this case, the function of environmental optimization is taken over by parks, "green zones" of the city as well as reservoirs, where representatives of the natural communities still overlive being protected. These habitats play important recreational, esthetic and conservation functions. On the other hand, these complexes are the sources of the human-induced introduction of new, alien species. In most cases, these species are introduced with the aim to improve the attractiveness, recreational value and protection against the aggressive influence of the city. Occasional invasions are also possible: targeted introduction by humans (SCALERA and GeNOvesi, 2016), fugitives from collections or aquaculture, "stowaways" during transportation etc. Environmental problems in cities (overconcentration of population, transport, industrial enterprises in a relatively small area) aggravate this situation. Often, the introduced aliens may act as dangerous invasive species. Numerous anthropophytes, due to their wide ecological valence, are not only able to occupy free ecological niches but they also can suppress the local native species.

*Corresponding author: e-mail:maryanaprokopuk406@gmail.com 
The distribution of alien species at urban areas is a prominent example of the consequences of anthropogenic transformation of the natural biota.

Due to their azonality and certain homogeneity of ecological conditions, aquatic ecosystems are convenient channels for invasion. Thus, in the fresh waters and seas of the southern Europe over the past 20-30 years, more than 300 alien species of all taxonomic groups of eukaryotes have been naturalized successfully (CIESM Atlas of exotic species in the Mediterranean, 2020). During this period, more than 100 alien species of aquatic organisms penetrated into the aquatic ecosystems of Ukraine (ZHUKYNSKYI et al., 2008).

Usually more attention is paid to the study of terrestrial species, so it is difficult to talk about the exact number and distribution of alien macrophytes species (OERTI, 2018). The risk of invasion by alien species is particularly high in cities, as the urban environment experiences a particularly high rate of plant introduction. In addition, aquatic freshwater ecosystems are particularly vulnerable to invasions by alien species compared with terrestrial ecosystems (LoDGE et al., 1998; SALA et al., 2000). Therefore, a lot of questions already explored regarding terrestrial plants in cities remain unresolved regarding aquatic plants (OERTI, 2018).

The relevance of this issue in the recent years is also evident from the number of the European researchers investigating this problem and from numerous publications related to the study of alien aquatic plants in Europe (HuSSNER, 2012; HuSSNER et al., 2014; OERTLI et al., 2018; HrivNAK at al., 2019).

In general, hydraulic engineering and water regulation have played a significant role in the increase of the alien species in Ukraine, especially the Dnipro River, which together with the Pripyat and Vistula River basins act as the main corridors for the alien species invasions from the Black Sea-Caspian region to Central and Western Europe, the Baltic Sea, and a vice versa.

Kyiv is located at the intersection of the European migration corridors. The aquatic habitats together with all the other biotopes formed within the city of Kyiv in particular, and in urban areas in general, differ in the degrees of transformation and hemeroby. Territories with excessive technogenic impact are the centers of introduction and subsequent migration of alien species into the natural biotopes (РRотороpova et al., 2002). The reservoirs and watercourses of Kyiv are characterized by significant anthropogenic eutrophication. All these factors control the diversity of macrophytes the predominance of the local eurytopic species as well as loss many stenotopic species and appearance of new alien components (ZUB et al., 2019).

There are 19 species of alien higher plants over the territory of Ukraine (ZUB and PROKOPUK, 2020). A total of 96 aquatic plant species have been recorded in Europe (in 46 European countries) (Hussner, 2012). Most alien aquatic plants are native to the North America, then to Asia and South America. Elodea canadensis is the most common alien aquatic plant in Europe, distributed in 41 European countries. The second place is occupied by Azolla filicu- loides (occurs in 25 countries), Vallisneria spiralis - in 22 and Elodea nuttallii - in 20 (HussNer, 2012). The history of macrophyte invasions on the European continent and the problems associated with this invasion have been widely discussed in scientific literature (SIMPSON, 1984; BARRAT-SEGRETAIN et al., 2002; JoSEFSSON, 2011).

The aim of this study was to provide objective information about the spreading of alien macrophytes in urban environment (on the example of Kyiv); establishing the features of their ecology, coenology, phenotypic and production variability of the model species, for next prevention of their introduction, distribution and naturalization.

Our study aim was to expand and supplement modern knowledge about macrophyte invasions in the surface freshwater bodies of Ukraine and about the factors that causing these invasions. This allowed us to identify the particularly aggressive (invasive) species exerting possible adverse effects on natural biodiversity, and to understand the role of anthropogenic transformation affecting the spreading of alien species of macrophytes. The research results can be used to indicate the changes in ecological conditions and in the structure of aquatic plants thickets in reservoirs inhabited actively developing by alien species of macrophytes.

\section{Materials and methods}

\section{Study sites}

In this article, we consider the urban ecosystem (based on the example of Kyiv City, Ukraine) as distribution site of for invasive species of higher aquatic plants. According to our knowledge, in this context, no detailed studies of water bodies in the city have been conducted yet, there exist only reports concerning isolated findings of alien macrophytes (CHORNA, 2006; BAGATSKA, 2007; LUSHPA, 2009; Karpova and KlePeTs, 2013; Heluta, 2013).

Kyiv is a large urban complex and the biggest city of Ukraine, with the largest area (83.6 thousand hectares) and the number of inhabitants (about 3 million people). It is characterized by a great number of parks and water bodies. Aquatic ecosystems within Kyiv City occupy 7\% of the total area of the city (almost $60 \mathrm{~km}^{2}$ ), most of them $\left(42 \mathrm{~km}^{2}\right)$ are hydro-habitats of the lotic type and only one third $\left(17 \mathrm{~km}^{2}\right)$ are lentic (DIDUKH and ALIOSHKINA, 2006). In total, there are 421 water bodies in the city; and the Dnipro River crosses the city from the north to the south for $\sim 35 \mathrm{~km}$. Aquatic habitats, like all other biotopes formed at urbanized territories, are more or less transformed and heterogeneous. Ponds, rivers and streams located within the Kyiv territory are characterized by a significant anthropogenic eutrophication.

\section{Field sampling}

The research samples were assembled in field surveys of ponds, rivers and streams located at the Kyiv territory. Seventy-two reservoirs have been surveyed and 45 localities of alien species of macrophytes have been 
identified. The studies were conducted during the period May-October 2013-2019, by methods conventional in hydrobotany (FASSETT, 1969; WoOD, 1975). Traditional hydrobiological and hydrobotanic methods were used: field surveys (by route and semi-stationary methods), marking of test sites, monitoring sites, ecological-coenotic profiles, hydrobotanical mapping of reservoirs; population studies, morphometric, coenotic, and production surveys, studies of trophic characteristics of biotope of anthropogenic eutrophication. Vegetation descriptions were carried out on sites with homogeneous conditions. For each place of growth, there were recorded: the geographical location, type of reservoir, depth, presence and speed of flow, nature of sediments, and water temperature. Biogenic contents $\left(\mathrm{NO}_{2}^{-}, \mathrm{NO}_{3}^{-}, \mathrm{NH}_{4}^{+}, \mathrm{PO}_{4}{ }^{3-}\right)$ were measured by the colorimetric method using DR900 Multiparameter Portable Colorimeter. The descriptions were made in accordance with the basic methodological principles of ecologicalfloristic classification J. Braun-Blanquet (Braun-BLANQUET, 1964). Total soil cover percentage (TSC) in each description site as well as particular soil cover percentage (PSC) for each plant species were estimated. The TSC and PSC were translated into the points accepted at the BraunBlanquet School.

\section{Data analysis and nomenclature}

The results of the research were processed by basic statistics and by the Principal component analysis PCA performed using the 'ade4' package (DrAY and DUfOuR, 2007) in R (R CORE TEAM, 2020). The scientific names of species of families are used in accordance with the International Plant Names Index (IPNI, 2020). The study of the adaptive strategy of alien plants in an urbanized environment was carried out after analyzing the scientific literature characterizing the process of invasion of alien species (Weber, 1997; Burda and IGNATYK, 2011; GAERTNER at al., 2017).

\section{Results}

The urban landscape of Kyiv City is characterized by a significant variety of water bodies. The wide range of habitats presented here and appropriate for good being of macrophytes determines their floristic richness. According to our research, today 62-65 species of macrophytes (about $40 \%$ of the floristic list of macrophytes of Ukraine) dwell here. In the natural flora, eurasian (34\%) and holarctic (28\%) species dominate, more than $23 \%$ of the floristic list consists of cosmopolitan species. In the zonal aspect, there are $51 \%$ of plurizonal and $30 \%$ of boreal type species.

The modern urban development of the Kyiv City mainly takes place due to water excavation of sand to the Dnipro River floodplain. As a result, there is a lot of drainage reservoirs - lakes, canals and cascades of ponds here. These are either transformed natural reservoirs or new artificial ones. Creation of such reservoirs causes formation of a number of new free biotopes suitable for coloniz- ation by macrophytes. These habitats make conditions for demutation successions. The pioneer stages of overgrowth of such biotopes are characterized by active penetration of alien species. About $11 \%$ of the list of the hydrophilic flora of the city are alien species. There are 10 species of alien macrophytes in the city (Hydrocharitaceae - 4 species, Acoraceae - 1 species, Araceae - 1 species, Azollaceae - 1 species, Lemnaceae - 1 species, Poaceae - 2 species) (Table 1).

Three species - Acorus calamus L., Elodea canadensis Michx. and Vallisneria spiralis L. can be considered as ancient invaders. These species are mentioned in the scientific botanical works of the late 19th-early 20 th centuries in the lists of flora of the city. Today, these plants are naturalized and became standard elements of the aquatic flora of urban water bodies. Since the middle of the 20th century Typha laxmannii Lepech. - the species of PontoCaspian origin had been added to this list. This species is more common in southern Ukraine. Kyiv is located on the border of the Polissia and Forest-steppe physical-geographical zones and until the middle of the last century, Typha laxmannii did not occur at its territory.

The sixteenth century is the approximate time of the invasion of Acorus calamus. Even 50-60 years ago, this species was widespread on the banks of the Dnipro River floodplain. Today, it occurs very rarely in the reservoirs of the city and only on the left bank of the Dnipro River. The reason for this is the almost total destruction of the floodplain landscape due to the urban development. This species does not form its own phytocoenosis, it occurs as

Table 1. Alien macrophytes of Kyiv

\begin{tabular}{cccc}
\hline & \multicolumn{3}{c}{ Distribution } \\
\cline { 2 - 4 } Species & $\begin{array}{c}\text { Early } \\
20 \text { th } \\
\text { century }\end{array}$ & $\begin{array}{c}\text { End } \\
\text { 20th } \\
\text { century }\end{array}$ & $\begin{array}{c}\text { Early } \\
21 \text { th } \\
\text { century }\end{array}$ \\
\hline Acorus calamus L. & + & + & + \\
Azolla caroliniana & - & - & + \\
Willd. & - & - & + \\
Egeria densa Planch. & - & & \\
Elodea canadensis & + & + & + \\
Michx. & & & + \\
E. nuttallii (Planch.) & - & - & + \\
H. St. John. & & & + \\
Lemna turionifera & - & - & + \\
Landolt. & & & + \\
Phragmites altissimus & - & - & + \\
(Benth.) Nabille & & & + \\
Pistia stratiotes L. & - & - & + \\
Typha laxmannii & - & + & + \\
Lepech. & & & + \\
Vallisneria spiralis L. & + & + & + \\
\hline
\end{tabular}


a component of communities belonging to the assotiations Calistegio-Phragmitetum V. Golub et Mirkin 1986 or Glycerietum maximae Hueck 1931.

Elodea canadensis occurs in eutrophic and mesoeutrophic waters (at a depth of $0.5-0.8 \mathrm{~m}$ on sandy and silt-sandy deposits). The typical components of coenoses with dominance of Elodea canadensis are Ceratophyllum demersum L., Stuckenia pectinata (L.) Börner, Myriophyllum spicatum L., Najas marina L. Elodea nuttallii H. St. John., Potamogeton crispus L.

Vallisneria spiralis is naturalized in the local native phytocoenosis, usually in reofilic biotopes (the watercourse of the Dnipro River and the channel associated with it) in sandy shallow waters with depths of $0.5-1.5 \mathrm{~m}$. It forms both monodominant coenoses and joint communities with Potamogeton perfoliatus L., P. heterophyllus Schreb.

Creation of the cascade of the Dnipro River reservoirs is associated with the expansion of Typha laxmannii over the water objects of the city. We recorded its first individuals in the 90 s of the last century along the newly built drainage channels of the city on disturbed sandy habitats. Today, this species has been fully naturalized and it forms fragmentary thickets along the banks of numerous channels, along with the associations of Phragmitetum communis (Gams. 1927) Schale 1939, Calistegio-Phragmitetum and Typhetum angustifoliae Pignatti 1953, Typhetum latifoliae G. Lang 1973.

The beginning of the 21 st century was characterized by an increase in the number of alien macrophytes in the reservoirs of the city more than 2 times (see Table 1). Over the past 10-15 years, six new alien macrophyte species have appeared: Azolla caroliniana Willd., Pistia stratiotes L., Lemna turionifera Landolt, Elodea nuttallii, Egeria densa Planch. and Phragmites altissimus Mabille. The ways of their penetration: purposeful (Azolla caroliniana, Pistia stratiotes) or accidental (Lemna turionifera, Elodea nuttallii, Egeria densa) release by humans. Phragmites altissimus can be considered as a transport - stowaway, extending from south to north with newly created biotopes of the Dnipro reservoir cascade. Most of them (Phragmites altissimus, Azolla caroliniana, Lemna turionifera, Pistia stratiotes and Egeria densa) occur in 1-3 localities.

The peculiarity of Phragmites altissimus is the attachment to anthropogenically-disturbed coastal natural and artificial ecotopes, it is common in reservoirs with increased recreational or technogenic impacts. In Kyiv, the species was first recorded by G.O. Karpova in the early 21 st century; only its 2 localities are known. The species forms monodominant coenoses with TSC $100 \%$, extending to the shores of reservoirs to a depth of $0.5 \mathrm{~m}$, on sandy sediments. The species populations are extremely productive - about $0.5 \mathrm{~kg} \mathrm{~m}^{-2}$ of dry phytomass is formed.

In 2014, there was recorded the development of Azolla caroliniana and Lemna turionifera in an artificial decorative pond of the city. The massive and rapid development of the communities of the Azolla caroliniana in the pond we observed is a striking example of invasion of an alien species. The species is the coenosis forming and dominant. The life strategy under conditions of the warm sum- mer-autumn of 2014 completely corresponded to the following "species-transformers": a species being, on the one hand, a donor of a resource (in particular, nitrogen), and on the other, an over-consumer of other resources in the habitat (light, oxygen, nutrients) causes changes to the coenotic structure of the community.

However, the development of coenoses of Azolla caroliniana was ephemeral, and in the following years (20152016), Azolla was not detected in the locality. The species is not winter-resistant and the thermophilic plant did not overwinter or spread through the hydrographic network of the Dnipro basin. But the specific microclimate of the city, with the warm winters observed lately, increases the species' ability to tolerate negative temperatures. Examples of rapid spreading of this species in southern Ukraine show that Azolla caroliniana is an extremely dangerous component of the macrophyte flora.

The duckweed Lemna turionifera compared to the native species (Lemna minor L., L. trisulca L. and L. gib$b a \mathrm{~L}$.) is more resistant to unfavorable climatic factors (droughts, severe frosts), primarily due to the formation of wintering turians. However, the environmental requirements for edaphic factors (low acidity of water, high trophic reservoir) in Lemna turionifera and the native species are quite similar, which gives a reason to expect further invasions of this species in the country.

Pistia stratiotes was first noted for Kyiv park ponds in 2006. Its introduction was probably intentional (release in nature), but unconscious. The species had a flash of development in the first year, but it did not overwinter. Since 2013, during 4 years we were observing the permanently existing coenopopulations of the species in three localities of the city. This species prefers flowing eutrophic water bodies with silty bottom sediments. Peak of development is in late summer-early autumn. During this time, it is a good recognized edificator of the complex of free-floating plants. Sometimes it achieves significant development, forms communities with TSC of $90 \%$, where the PSC of the plant in the phytocoenosis was $70-80 \%$. It occurs as a part of two communities: in coenoses where Ceratophyllum demersum L. (PSC of Pistia stratiotes in phytocoenosis is $70 \%$ ) was a subdominant, and as. Lemnetum minoris Soó 1927 where Lemna minor dominates (PSC $60 \%$ ), and Pistia stratiotes is subdominant (PSC 30\%). In 2018, data on the penetration of Pistia stratiotes into the Dnipro River hydro-network in the city area were assembled.

Elodea nuttallii, prefering meso-eutrophic and eutrophic, low-flow reservoirs, grows on a depth of up to $1.5 \mathrm{~m}$ and slightly silted sandy bottom sediments. Usually it is a subdominant (PSC 25-75\%) in communities of Ceratophyllum demersum, also occurred in the thickets of Myriophyllum spicatum L., Trapa natans L., Hydrocharis morsus-ranae L., Stuckenia pectinata, Nuphor lutea L., Salvinia natans (L.) All., Najas marina L., Najas minor All. It forms communities Elodeeto-Ceratophylletum, Elodeeto-Potamogetum. Today there is a clear trend of Elodea nuttallii moving up and down the Dnipro River.

Four localities of Egeria densa are known in the city and its surroundings today. These localities are situated 
in the floodplain reservoirs and channels on the left bank of the Dnipro River. The development of thickets has a fluctuating character: the plant is capable to outbreaks of mass development and attenuation, up to the complete temporary elimination from the hydrophytocoenosis of the reservoir. In the water bodies in Kyiv, the growing season of the species begins quite late. The mass development of the communities is observed towards the end of August-the beginning of September, when water warms above $20{ }^{\circ} \mathrm{C}$. Egeria densa prefers areas with good water exchange (gravitates to canals, floodplain lakes that have not lost a connection with the main stream, streams with a little flow). It is distributed at sandy shallows to a depth of $1.0 \mathrm{~m}$. In the given phytocoenosis, it can be recognised as monodominant (PSC 80-90\%) and subdominant (PSC 20-30\%); or it forms communities Egerietun densa and Egerieto-Ceratophylletum. In thickets the species forms significant phytomass $-0.225-0.450 \mathrm{~kg} \mathrm{~m}^{-2}$ (wet phytomass).

The PCA method allowed us to identify two main components demonstrating a variety of conditions controlling the formation of phytomass in coenopopulations with the dominance of Elodea: water temperature, nitrite, nitrate, ammonium, total nitrogen and phosphates (Fig. 1). The greatest contribution to the first component is the content of mineral nitrogen compounds, that is, the variation of this factor most determines the diversity of conditions. A smaller contribution to the first component makes the content of phosphates. It should be noted that these main factors have the opposite contribution to the first component: the growth of one of them is accompanied by the decrease of the other. In the second main component, which is not related to the first one, the greatest contribution is made by ammonium, the content of which in water bod- ies correlates with temperature. High phytomass values of coenopopulations of Elodea are formed under conditions of lower water temperature and lower ammonium content or low nitrate and nitrite content in water. The effect of phosphate content in water on productive indicators is less obvious.

The significant variations in morphometric and production parameters both in different coenopopulations and whithin one local populations of these species indicate the plasticity of these species over the studied region (Fig. 2). For example, analysis of the dynamics of phytomass values within the local populations of Elodea revealed a greater variability in phytomass produced by Elodea nuttallii communities than Elodea canadensis, which is common for species in the first stages of invasion.

Significant variability of morphometric parameters of coenopopulations of alien species formed in different environmental conditions was also indicated. The analysis showed that individuals of Pistia stratiotes from eutrophic water bodies formed significantly larger surface organs (the maximum values of such parameters as the diameter of the rosette, the length of the leaf blade, the number of veins on the leaf blade); but individuals from the mesoeutrophic reservoir had a larger number of leaves in the rosette, the number of roots and their length (Fig. 3).

\section{Discussion}

At present, the invasions of alien species into the city water bodies exhibit an early stage: only 7 species were recorded in Kyiv nowadays. They represent $53 \%$ of the complete list of macrophytes alien species of (ZUB and Prokopuk, 2020) occurring in Ukraine and $11 \%$ of the

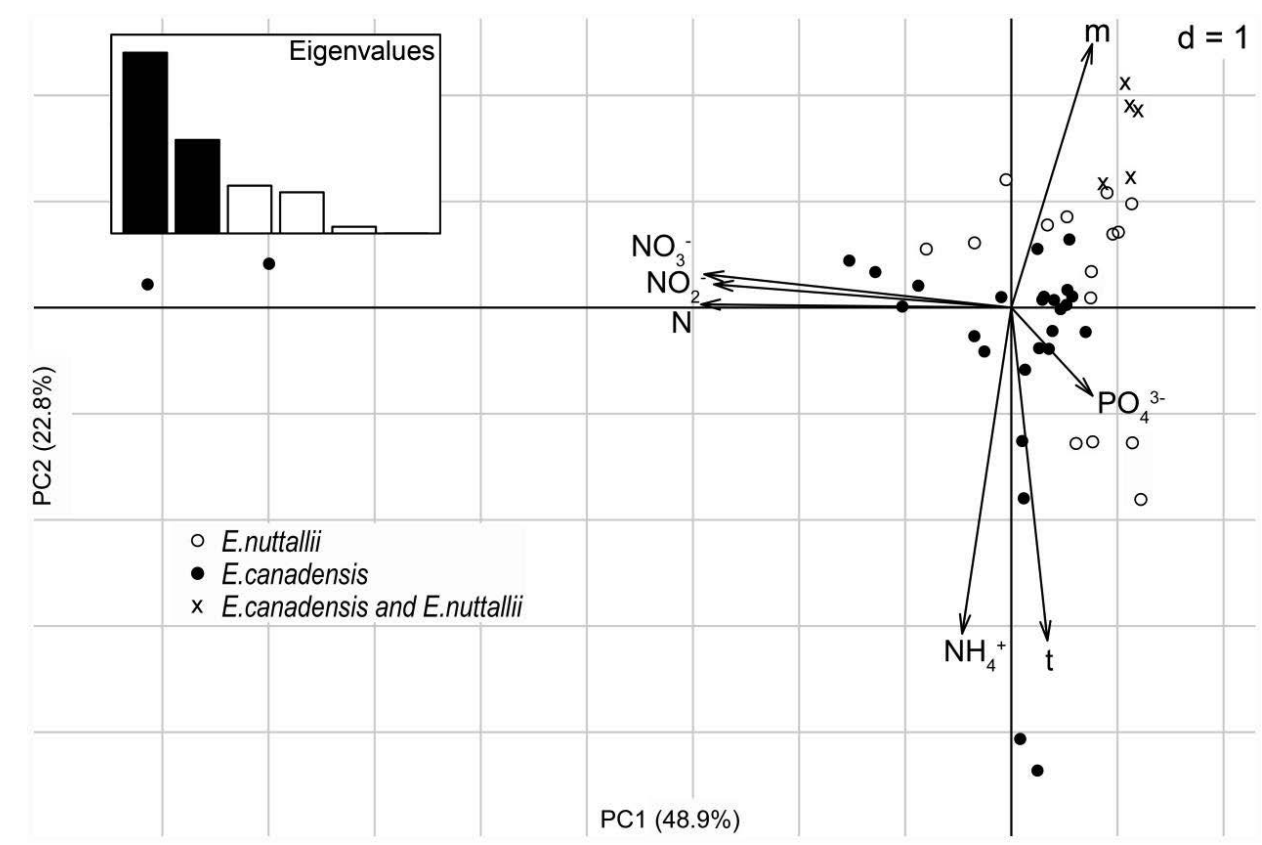

Fig. 1. Factors influencing the formation of coenopopulations in Elodea canadensis, Elodea nuttallii evaluated by PCA method. 
a

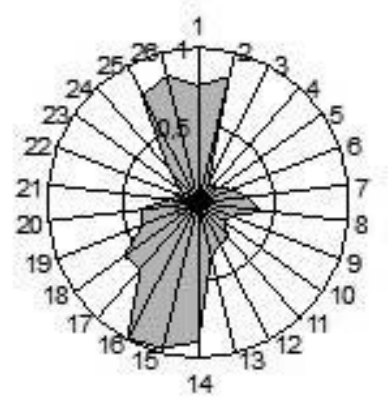

b

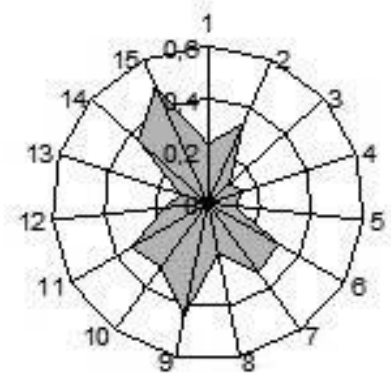

Fig. 2. Examples of variation of phytomass amount in Elodea nuttallii (a) and Elodea canadensis (b) (air-dry, $\mathrm{kg} \mathrm{m}^{-2}$ ) within local coenopopulations. The scale of values is on the radius, and the ordinal numbers of the individuals are situated around the circle.

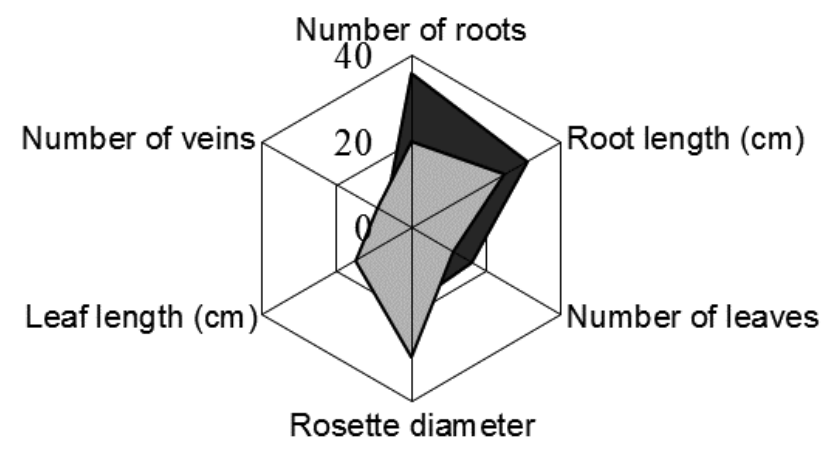

aeso-eutrothic pond

口Eutrothic pond

Fig. 3. Variation of the main morphometric parameters of Pistia stratiotes in different reservoirs.

aquatic flora of the city. For comparison, 23 taxa of alien aquatic plants $(17 \%$ of the city aquatic flora) were registered in 178 ponds in other large European city - Geneva, with five of them at a high risk of invasion (OERTLI et al., 2018). The largest numbers have been reported from Italy and France (34 species), followed by Germany (27), Belgium and Hungary (26) and the Netherlands (24) (HussNER, 2012). But this number is rising sharply and has doubled over nearly 30 years in Germany (HusSNER et al., 2014). In Slovakia, there has been recognised a significant increase in the number of alien species, due to the increase in the number of intensive studies on aquatic vegetation accomplished over the past 30 years. Twenty alien aquatic plants were registered in the 479 research localities (HrivnAK at al., 2019). Dunn and Heneghan (DunN and HeNEGHAN, 2011) report that the flora in the largest cities includes around 30 to $50 \%$ alien species. Oertli and the authors note that urban environments are particularly predisposed to the deliberate introduction of alien plants. The introduction of cultivated plants into urban ecosystems can be accidental or non-accidental, associated with ornamental horticulture (e.g. garden ponds) or trade in aquarium plants. Hrivnak and colleagues also link the presence of alien species with the deliberate introduction of aquatic and ornamental plants as well as the supportive impacts of the rising temperatures and intensive landscape modification (HrIVNAK at al., 2019). Consequently, the constant climate change and increasing land use are leading to increased invasiveness and accelerated spreading of alien species over new habitats.

For example, in 1899, Elodea canadensis was recorded $20 \mathrm{~km}$ from Kyiv in the lakes on the left side of the Dnipro River (ERLICH, 1899). The plant fell into the natural water bodies due to the lack of attention of a gardener of the Botanical Gardens, and by the flood in 1899 it was spread to the water bodies of the outskirts of Kyiv. Half a century later, Elodea became a common plant in most water bodies in Ukraine. The famous Ukrainian botanists M.V. Charleman (Charleman, 1914; Charleman, 1921) and K. K. Zerov (Zerov, 1939) list Elodea as a common species of aquatic flora in their floristic lists for the urban environment. In the period of $30-40$ years ago, the species was massive distributed and formed monodominant thickets in decorative ponds and water bodies at the remainders of the floodplain system within the city territory. Recent studies show a significant decrease in its coenotic activity: in a number of reservoirs Elodea canadensis in macrophyte communities has changed its status from 
a coenosis-forming to a sporadically occurring species or it has disappeared completely (ZUB et al., 2019). This can be explained by the significant anthropogenic eutrophication of the water reservoirs in the city.

The scientific works written by I. F. Schmalhausen at the end of the 19th century document his individual finds of Vallisneria spiralis for the outskirts of the city (SCHMALHAUSEN, 1886). However, the mass distribution and development of this species increased after the construction of the cascade of the Dnipro reservoirs in the 1950s and 1970s. In the mid-70s of the last century, thickets of this species occurred in the shallow waters of the riverbed of the Dnipro and Desna Rivers in the city area.

The species Elodea nuttallii started its invasion to the aquatic biotopes of Ukraine from the streams of Kyiv (the species was first recorded in 2004 in the bay of Kaniv reservoir, downstream $100 \mathrm{~km}$ from Kyiv (CHORNA et al., 2006). Egeria densa also started spreading along the Ukraine hydro-network from Kyiv (BAGATSKA, 2007). According to the scientists, the species was transferred into natural streams by accident.

The state of all macrophyte thickets, including alien species, is affected by the water body type. The hydrographic characteristics determine the structure of thickets and of the ecological groups of macrophytes that the thickets consist of. The biochemical characteristics (including water quality), on the other hand, determine the species composition. All the studied water bodies belong to the hydrographic network of the Dnipro River. The great majority of the findings of free-floating macrophytes (Azolla caroliniana, Lemna turionifera, Pistia stratiotes) and emergent plants (Acorus calamus, Phragmites altissimus, Typha laxmannii) belonged to the water bodies of the lentic type with difficult water exchange, while the alien submerged plants (Vallisneria spiralis, Elodea canadensis, E. nuttallii, Egeria densa) were spreading the lotic ecosystems.

The analysis of the ecological preferences of alien species in urban water bodies in Kyiv showed that they all prefered reservoirs with a high trophic status (from mesoeutrophic to eutrophic). Nutrient-rich habitats are required for sreading of Azolla caroliniana and Pistia stratiotes. Phosphate contamination of reservoirs is a probable limiting factor for the development of Azolla caroliniana. Pistia stratiotes prefers biotopes rich in mineral phosphorus compounds. The limiting factor for the development of coenopopulations is either the lack or excess of mineral nitrogen compounds in the water. The ecological preferences of the species relative to this indicator are within the meso-eutrophic waters. The behaviour of Lemna turionifera in the specified phytocoenosis is completely consistent with the literature data, since this species in Europe (UoTILA, 2009; SINKEVIČENE், 2011) occurs as a co-dominant or asectator in the associations of the Lemnetum minoris Soó 1927 or Lemno-Spirodeletum polyrrhizae Koch 194, spreading over illuminated shallow areas of non-flowing and slow-flowing eutrophic reservoirs, well warmed, with a water reaction close to neutral.
Egeria densa and Elodea nuttallii, in comparison with Elodea canadensis, are characterized by a wider ecological valence in terms of the content of nitrogen compounds in the water. The environmental preferences of Elodea canadensis are connected with oligo-mesosaprobic and meso-eutrophic water; contrarily, the excess of phosphates is a limiting factor for the development of coenopopulations of this species. For Elodea nuttallii, increased concentrations of mineral nitrogen and reduction of phosphate content can be considered as limiting factors for the phytomass production. The plant elongation and reduction of leaf width in Elodea canadensis as well as the reduction or "compaction" of plant habitus and increase in leaf width in Elodea nuttallii are indicators of the progressing biotope eutrophication; elongation and more intensive branching of Elodea nuttallii individuals confirm the high water quality and reophilic conditions in the biotope.

Alien species of macrophytes distributed in the city reservoirs are characterized by wide ecological amplitudes, stress tolerance, reproduction rate, high degree of naturalization, allowing the plants to use the resources of the new environment that were inaccessible to the native species (ZuB et al., 2019), and, in this way, to affect significantly the homeostasis of the ecosystem and to transform this ecosystem.

The strong variations in morphometric and production parameters both in different coenopopulations and whithin one local populations of these species indicate the plasticity of these species over the studed region. The analysis of the dynamics of phytomass values within the local Elodea populations showed more variability of phytomass produced by Elodea nuttallii communities than by Elodea canadensis, which is characteristic for the species in the initial invasion stages .

\section{Conclusions}

Seven species of alien aquatic macrophytes were found within the territory of the Kyiv City, which represent $11 \%$ of the hydrophilic flora of the city. The great variations in morphometric and production parameters both in different coenopopulations and whithin one local population of these species indicate their plasticity in urban water bodies. In our opinion, anthropogenic eutrophication of water bodies in urban areas due to nitrogen-containing biogenic compounds can contribute to the alien species introduction. The recent invasions representatives Egeria densa, Elodea nuttallii and Pistia stratiotes, in comparison with Elodea canadensis are characterized by a wider ecological valence concerning the content of compounds of nitrogen in water. The alien macrophytes species distributed in the city reservoirs are characterized by wide ecological amplitudes, stress tolerance, reproduction rate, as well as high degree of naturalization, which allow them to use the resources from the new environment inaccessible to the native species and to affect significantly the homeostasis of the ecosystem and its transformation. 


\section{Acknowledgement}

Special thanks to the Candidate of Biological Sciences Maltsev V.I. for the help with the editing of the scientific English of manuscript and the Doctor of Biological Sciences Netsvetov M.V. for assistance in statistical data analysis.

\section{References}

BagatsKa, T.S., 2007. Egeria densa Planchon (Hydrocharitaceae) - novyi vyd dlia materykovoi chastyny Ukrainy [Egeria densa Planchon (Hydrocharitaceae) - a new species for the mainland of Ukraine]. Ukrainskyi Botanichnyi Zhurnal, 64 (6): 914-916.

Barrat-Segretain M-H., Elger A., Sagnes P., Puijalon S., 2002. Comprehension of three life-history traits of invasive Elodea canadensis Michx. and Elodea nuttallii (Planch.) H. St. John. Aquatic Botany, 74: 299-313.

Braun-Blanquet, J., 1964. Pflanzensoziologie. Grundzüge der Vegetationskunde [Plant sociology. Fundamentals of vegetation science]. 3 Aufl. Wien-New York: SpringerVerlag. $865 \mathrm{~s}$.

Burda, R.I., IgNaTyuk, O.A., 2011. Metodyka doslidzhennia adaptyvnoi stratehii chuzhoridnykh vydiv roslyn $v$ urbanizovanomu seredovyshchi [Methods of study of adaptive strategy of alien plant species in urban environment]. Kiev: NTsEBM NAN Ukrainy; Vipol. 112 p.

Charleman, M.V., 1914. Ocherk Truhanova (Alekseevskogo) ostrova [Essay of Trukhanov (Alekseevsky) Island]. Kiev. 21 p.

Charleman, M.V., 1921. Po Kyievy i yoho okolytsyakh. Korotkyi providnyk dlia pryrodnychykh Ekskursii [Kiev and its surroundings. A short guide]. Kiev: Vydavnytstvo DVU. $48 \mathrm{p}$

Chorna, G.A., Protopopova, V.V., Shevera, M.V. FedoRONCHUK, M.M., 2006. Elodea nuttallii (Planch.) H. St. John (Hydrocharitaceae) - novyi dlya flory Ukrainy vyd [Elodea nuttallii (Planch.) H. St. John (Hydrocharitaceae) - new species for the flora of Ukraine]. Ukrainskyi Botanichnyi Zhurnal, 63 (3): 328-331.

CIESM Atlas of exotic species in the Mediterranean, 2020. [online]. [cit. 30-03-2020]. http://www.ciesm.org/online/ atlas/intro.htm

Didukh,Y., AlioshKina, U., 2006. Klasyfikatsiia ekotopiv mista Kyieva [Ecotope classification of Kyiv]. Naukovi Zapysky NaUKMA. Biolohiia ta Ekolohiia, 54: 50-57.

DraY, S., Dufour A-B., 2007. The ade4 package: implementing the duality diagram for ecologist. Journal of Statistical Software, 22 (4): 1-20.

Dunn, C., Henegham, L., 2011. Composition and diversity of urban vegetation. In NiEMELÄ, J. (ed.). Urban ecology. Patterns, processes, and applications. Oxford: Oxford University Press, p. 103-115. https:// doi.org/10.1093/ac prof:oso/9780199563562.003.0013

ERLICH, J. E., 1899. Elodea canadensis. Wszechświat, 44: 697.

FASSETT, N.C., 1969. A manual of aquatic plants. Madison: University of Wisconsin Press. 405 p.

Gaertner, M., Wilson, J.R.U., Cadotte, M.W., Maclyor,
S.J., ZenNi, D.R., Richardson, M.D., 2017. Non-native species in urban environments: patterns, processes, impacts and challenges. Biological Invasions, 19: 34613469. doi: 10.1007/s10530-017-1598-7

Heluta, V., 2013. Image of Pistia stratiotes L. In Plantarium: openon-lineatlas andkeytoplants andlichensofRussiaand neighbouring countries. 2007-2020. [online]. [cit. 10-032020]. https://www.plantarium.ru/page/image/id/204275 .html

HrivnÁk, R., Medvecká, J., BalážI, P., Bubíková, K., OŤAHELová, H., SvitoK, M., 2019. Alien aquatic plants in Slovakia over 130 years: historical overview, current distribution and future perspectives. NeoBiota, 49: 3756. https://doi.org/10.3897/neobiota.49.34318

Hussner, A., 2012. Alien aquatic plant species in European countries. Weed Research, 52 (4): 297-306. https://doi. org/10.1111/j.1365-3180. 2012.00926.x

Hussner, A., Nehring, S., Hilt, S., 2014. From first reports to successful control: a plea for improved management of alien aquatic plant species in Germany. Hydrobiologia, 737 (1): 321-331. https://doi.org/10.1007/s10750-013$1757-5$

IPNI, 2020. International plant names index. [online]. The Royal Botanic Gardens, Kew; Harward University Herbaria \& Libraries; Australian National Botanic Gardens. [cit. 07-08-2020]. http://www.ipni.org

JosefsSON, M., 2011. Elodea canadensis, Elodea nuttallii, Elodea callitrichoides. In NOBANIS. European Network on Invasive Alien Species. [online]. [cit. 11-03-2020]. www.nobanis.org

KarPova, G.O., KlePets, O.V., 2013. Osoblyvosti poshyrennia ocheretu naivyshchoho (Phragmites altissimus (Benth.) Nabille) v umovakh urbolandshaftu [The features of the distribution of the highest reed (Phragmites altissimus (Benth.) Nabille) in urban landscape]. In 3rd international scientific conference "Plant and urbanization". Dnipropetrovsk, 19-20 March, 2013. Conference materials. Dnipropetrovsk: TOV TVH "Kunitsa", p. 15-18.

Kasselmann, C., 1995. Aquarienpflanzen. Stuttgart: E. Ulmer. $472 \mathrm{p}$.

Keating, M., 1993. The Earth Summit's agenda for change: a plain language version of Agenda 21 and the other Rio Agreements. Geneva, Switzerland: Centre for Our Common Future. 70 p.

LANDOLT, E., 1975. Morphological differentiation and geographical distribution of the Lemna gibba - Lemna minor group. Aquatic Botany, 1: 345-363.

Lodge, D.M., Stein, R.A., Brown, K.M., Covich, A.P., Bronmark, C., Garvey, J.E., Klosiewski, S.P., 1998. Predicting impact of fresh water exotic species on native biodiversity: challenges in spatial scaling. Australian Journal of Ecology, 23 (1): 53-67. https://doi. org/10.1111/j.1442-9993.1998.tb00705.x

LushPA, V.I., 2013. Vodyanyi latuk (Pistia stratiotes L.) u Holosiivskomu stavku m. Kyieva [Water lettuce (Pistia stratiotes L.) in Holosiivsky pond in Kyiv]. Naukovyi visnyk NUBiP Ukrainy, 134: 147-152.

Oertli, B., Boissezon, A., Rosset, V., Ilg, C., 2018. Alien aquatic plants in wetlands of a large European city (Geneva, Switzerland): from diagnosis to risk assessment. Urban Ecosystems, 21 (2): 245-261. doi.org/10.1007/ s11252-017-0719-5 
ProkopuK, M.S. 2016. New record of Azolla caroliniana in water bodies of Kiev. Hydrobiological Journal, 52 (2): 54-58. doi: 10.1615/HydrobJ.v52.i2.60

Sala, O., Chapin, F., Armesto, J., Berlow, E., Bloomfield, J., Dirzo, R., Huber-Sanwald, E., Huenneke, L., Jackson, R., Kinzing, A., Leemans, R., Lodge, D., Mooney, H., Oesterheld, M., Poff, N., Sykes, M., Walker, B., Walker, M., Wall, D., 2000. Biodiversityglobal biodiversity scenarios for the year 2100. Science, 287 (5459): 1770-1774. https://doi.org/10.1126/ science.287.5459.1770

Scalera, R., Genovesi, P., 2016. Guidance for governments concerning invasive alien species pathways action plan. Convention on the conservation of European wildlife and natural habitats. [online]. Final draft. T-PVS/ $\operatorname{Inf}(2016) 10.39$ p. [cit. 2020-03-27].

Shmalhauzen, I.F., 1886. Flora Yuho-Zapadnoi Rosii, t.e. hubernii Kiievskoi, Volynskoi, Podolskoi, Poltavskoi, Chernihovskoi i smiezhnykh miesnostiei [Flora of Southwest Russia, i.e the provinces of Kyiv, Volyn, Podolsky, Poltava, Chernihiv and related areas]. Kiev. 783 p.

SimPSON, D.A., 1984. A short history of the introduction and spread of Elodea Michx. in the British Isles. Watsonia, 15:1-9.

SINKEVIČENĖ, Z., 2011. First records of Lemna turionifera in Lithuania. Botanica Lithuanica, 7 (1): 59-61.

R CORE TEAM, 2020. $R$ - a language and environment for statistical computing. Vienna: $\mathrm{R}$ foundation for statistical computing. [online]. [cit. 27-04-2020]. https://www.rproject.org/

Uotila, P., 2009. Lemnaceae. In Euro+Med PlantBase - the information resource for Euro- Mediterranean plant diversity. [online]. [cit. 2018-04-19]. http://ww2.bgbm.org/
EuroPlusMed/PTaxonDetail.asp?NameId=95604\&PTRe $\mathrm{fFk}=7300000$

WeBER, E.F., 1997. The alien flora of Europe: a taxonomic and biogeographic overview. Vegetation Science, 8: 565-572.

Wood, R.D., 1975. Hydrobotanical methods. Baltimore: University Park Press. 173 p.

Zerov, D.K., 1939. Vyshcha vodyana roslynnist zaplavnykh vodoim r. Dnipra v okolytsyakh zapovidnyka AN URSR "Horyste" [Higher aquatic vegetation of the Dnieper River around the Goriste Reserve of the Academy of Sciences of the Ukrainian SSR]. Trudy Hidrobiolohichnoi Stantsii, 17: 11-38.

ZhUKINSKIJ V.N., MARChENKo T.A., LYASHENKo A.V., 2008. Adventivnye vidy i izmenenie arealov aborigenny gidrobiontov v poverhnostnyh vodnyh ob'ektah Ukrainy. Soobshchenie 3. Itogovoe osuzhdenie [Adventive species and changes in area of distribution of aboriginal hydrobionts in surface water bodies of Ukraine. Report 3. Concluding discussion]. Gidrobiologicheskiy Zhurnal, 43 (4): 3-24.

Zub, L.N., Prokopuk, M.S., 2020. Osobiennosti invazii makrofitov v vodnye ekosystemy Sredneho Prydneprovia (Ukraina) [The features of macrophyte invasions in the aquatic ecosystems of Middle Dnipro Region (Ukraine)]. Rossiiskyi Zhurnal Biolohichnykh Invazii, 1: 8-19.

Zub, L.N., Prokopuk, M.S., Pohorelova, Yu.V., 2019. Species composition of higher aquatic plants of urban water bodies as the index of enviromental quality. Hydrobiological Journal, 55 (2): 43-53. doi: 10.1615/HydrobJ. v55.i2.40

Received April 16, 2020 Accepted September 17, 2020 